\title{
Maize landraces management to avoid transgenic contamination, decreases yield and seed quality
}

\author{
Anderson Munarini ${ }^{1}$ (D), Daniele Nerling² (iD, Cileide Maria Medeiros Coelho² ${ }^{\text {ID }}$, Rubens \\ Onofre Nodari ${ }^{3, \star}$ (i) \\ 1. Universidade Federal de Santa Catarina - Programa de Pós-Graduação em Recursos Genéticos Vegetais - Florianópolis (SC), Brazil. \\ 2. Universidade do Estado de Santa Catarina - Departamento de Agronomia - Lages (SC), Brazil. \\ 3. Universidade Federal de Santa Catarina - Departamento de Fitotecnia - Florianópolis (SC), Brazil. \\ Received: Sep. 25, 2020 | Accepted: Apr. 26, 2021 \\ Section Editor: Mauro Guida dos Santos \\ *Corresponding author: rubens.nodari@ufsc.br \\ How to cite: Munarini, A., Nerling, D., Coelho, C. M. M. and Nodari, R. O. (2021). Maize landraces management to avoid transgenic \\ contamination, decreases yield and seed quality. Bragantia, 80, e3921. https://doi.org/10.1590/1678-4499.20200421
}

\begin{abstract}
Producing high-quality seeds for agroecological agriculture is needed because the plants will be exposed to a diversity of environments and management practices. Sowing times and population densities can influence the quality of seeds produced by landraces. Further, seeds for agroecological cultivation must not be contaminated by transgenes. In this context, it is necessary to know the agronomic performance of landraces outside of the recommended growing period to avoid gene flow with transgenic cultivars. Thus, the objective of this work was to determine the germination rate, vigor and sanitary quality of seeds of maize genotypes cultivated in an agroecological system at different sowing times and densities. A split-split-plot design was used in the 2016/2017 and 2017/2018 growing seasons. The physiological quality evaluation was based on germination and vigor tests, and the sanitary quality was obtained by visually examining the seeds. The results showed a significant simple effect of genotype, sowing time and density, as well as double and triple interactions among factors for all evaluated traits. The most suitable time for sowing the corn landraces evaluated in an agroecological system in western Santa Catarina is September, when the seeds exhibited the highest percentage of germination and vigor and there was a lower incidence of pathogens. At this time, a density of 55,000 plants ha $^{-1}$ had the best result for germination. Late sowing was tested to avoid gene flow from transgenic varieties that usually are sown in September, but the results indicated penalties, such as a decrease in seed yield and quality.

Key words: Zea mays ssp. mays L., germination, vigor, temporal isolation, genetically modified organism.
\end{abstract}

\section{INTRODUCTION}

Brazil, in addition to having high biodiversity, is a major food producer and part of this food comes from organic and agroecological systems. Agroecological principles, such as crop diversification, heterogeneous varieties, organic soil management and water conservation, reduce vulnerability to climate change effects (Altieri et al. 2015).

In these agricultural systems, instead of highly homogeneous cultivars, farmers use landraces or local varieties of heterogeneous genotypes (Zeven 1998). Specifically, in the municipalities of Anchieta and Guaraciaba, in western Santa Catarina state, Brazil, it was found there are 2049 small farms with 1513 populations of maize landraces (Costa et al. 2017). The authors note that the region is a microcenter of Zea mays L. Small farmers across the country continuously save, reuse and exchange landrace seeds with neighbors, which favors genetic diversity and in situ on-farm conservation. Harlan (1951) designed microcenters of diversity when a significant diversity is accumulated within a very restricted geographical area.

In this scenario, landraces become important seed sources in all agricultural systems, favoring the adoption of sustainable practices. In addition, landraces can produce more than 7.0 tons per hectare in organic systems (Balbinot Junior et al. 2005; 
Machado et al. 2011). Although, organic and agroecological management practices have been developed to cultivate maize as an alternative to conventional agricultural systems (Araujo et al. 2013), there are still not enough organic seeds to fulfill the demand of the seed producers and organic farmers that grow for food, since the entire organic food chain requires using only organic components. Noting that the reduced supply of organic corn seeds on the market, added to the scarcity of information on production and their quality are among the main obstacles to the production of organic maize in Brazil, Martin et al. (2018) showed that seeds of two maize landraces showed high vigor and germination percentage (>95\%) after 90 days of storage in plastic bottles. Nevertheless, there are few studies related to the landrace quality of seeds, particularly related to vigor and germination rate standards produced in agroecological systems.

The isolation of seed production fields is one of the determining factors for the production of quality maize seeds in organic and agroecological systems (Martin et al. 2007). For seed production, normative instruction No. 45 of the Ministry of Agriculture, Livestock and Supply establishes a minimum spatial isolation of $200 \mathrm{~m}$ or, alternatively, a minimum temporal isolation of 30 days between the flowering times of maize fields (Brazil 2013). In the same region where the present study was carried out, western Santa Catarina, Brazil, is recognized as a microcenter of maize diversity (Costa et al. 2017). Since $17,1 \%$ of maize production are landraces (IBGE 2017) cultivated in small farms $(<10 \mathrm{ha})$, the spatial isolation, to avoid transgenic contamination of landraces, cannot be applied because of the proximity to transgenic variety fields. Therefore, since organic and agroecological production usually occur on small properties, spatial isolation is impractical.

In this context, temporal isolation could be an option; however, an inadequate sowing time can negatively affect plant traits and yield (Amorim et al. 2011), composition (Jaureguy et al. 2013) and physiological quality of seeds (Bornhofen et al. 2015; Rahman et al. 2013). Therefore, it remains to be tested if temporal isolation to avoid transgenic contamination interferes with the yield and quality of seeds in agroecological systems.

Studies that evaluate the production of maize seeds in agroecological systems and consider different sowing times and population arrangements are scarce. Even within the same zone, there is wide variation in photoperiodic conditions, solar radiation and temperature, which influence yield components and qualitative attributes of seeds (Bornhofen et al. 2015; Mazvimbakupa et al. 2015). Thus, studies about sowing time for each specific environmental condition and cultivation system (Amorim et al. 2011; Meotti et al. 2012), particularly in a maize diversity-rich region, are important to subsidize management practices in order to improve the agronomic performance of crops. The objective of this work was to evaluate the germination rate, vigor and sanitary attributes of maize landrace seeds produced in agroecological systems under different sowing times and densities, designed to avoid transgenic contamination and compensate for putative decrease yield and seed quality.

\section{METHODS}

\section{Experimental design}

The seed production field was on a small family farm located in Chapecó, Santa Catarina, Brazil ( $\left.27^{\circ} 03^{\prime} 21^{\prime \prime} \mathrm{S} ; 52^{\circ} 40^{\prime} 07^{\prime \prime} \mathrm{W}\right)$. The experiment, installed in an area at least $500 \mathrm{~m}$ away from another maize crop, was carried out in split-split-plot with three replications. The main plot represented the sowing times, the split-plot represented the genotypes, and the splitsplit-plot represented the sowing density. The experiments were installed during the first half of September (sowing time 1 - ST1), first half of November (sowing time 2 - ST2) and first half of January (sowing time 3 - ST3) in the 2016/2017 and 2017/2018 growing seasons. The sowing densities used were 2.5, 4.0, 5.5 and 7.0 plants. $\mathrm{m}^{-1}$ (thereafter SD1, SD2, SD3 and SD4, respectively). Three landraces (Branco Precoce, Taquara and Língua de Papagaio) cultivated by farmers in the region, and an open pollination variety (SCS 155 Catarina), was used as a control for the growing region.

The ears of ST1, ST2 and ST3 were harvested in the first half of January, mid-March and the first half of June for each growing season, when the seeds reached $20 \%$ moisture content. The ears produced in each plot were harvested manually, threshed and the seeds were dried in the shade until they reached approximately $13 \%$ moisture content. An average seed sample of $1000 \mathrm{~g}$ of each treatment was homogenized and divided to obtain four repetitions of $250 \mathrm{~g}$ (Coelho et al. 2010), 
which were used in assessments of physiological and sanitary quality. The physical and physiological analyses of the seeds were carried out at the Seed Analysis Laboratory of the Agroveterinary Center, Universidade para o Desenvolvimento do Estado de Santa Catarina.

\section{Germination test (GT)}

Fifty seeds were used per repetition, arranged on sheets of germitest paper as the substrate. The paper sheets were previously moistened with distilled water in the amount of two and a half times the weight of the dry paper. After the seeds were scattered, the paper sheets were placed in a Magensdorf-type germinator at $25^{\circ} \mathrm{C}$. The first count was performed on day four and the final count was performed on day seven after the test initiated (Brazil 2009).

\section{Accelerated aging (AA)}

Accelerated aging was used to determine the vigor (Marcos-Filho 2005). Again, 50 seeds per repetition were placed to age in a plastic gerbox containing $40 \mathrm{~mL}$ of distilled water. The seeds were distributed in a single and uniform layer on a stainless-steel screen at the bottom of the gerbox. The boxes were kept in an aging chamber at $45^{\circ} \mathrm{C}$ for $72 \mathrm{~h}$. After the aging period, the seeds were placed to germinate; after four days, an evaluation of normal seedlings was carried out as described in the Rules for Seed Analysis (Brazil 2009).

\section{Health test}

The seeds of each repetition were examined visually and those that presented typical symptoms or signs of pathogenic agents, such as Fusarium spp., Stenocarpella maydis and Stenocarpella macrospora, were separated and counted (Brazil 2009). The results (incidence of pathogens) were expressed as a percentage of the ratio seeds with pathogens to total evaluated seeds.

\section{Weather data}

The monthly average of rainfall, radiation and temperatures from January 01, 2008 through December 31, 2018 were obtained from the Foz do Chapecó Energia S.A. In addition to the same data specifically from September 1, 2016 through May 31, 2018, the average minimum temperatures and average maximum temperatures were obtained from the automated weather station ( $27^{\circ} 05^{\prime} 24^{\prime \prime}$ ' $52^{\circ} 38^{\prime} 05^{\prime}$ W), located at Empresa de Pesquisa Agropecuária e Extensão Rural de Santa Catarina, Chapecó, SC, Brazil (http://ciram.epagri.sc.gov.br/) $5 \mathrm{~km}$ apart from the experimental. The weather data (Fig. 1) were used to discuss the obtained results.

\section{Statistical analyses}

The germination test and accelerated aging data were transformed using arcsen $\sqrt{x}_{\mathrm{x}} / 100$ to meet the theoretical assumptions of the F-test (normality and homogeneity). Then, the data were subjected to a joint analysis of variance and when a significant difference was detected by the F-test, their means were compared by Tukey's test, $\mathrm{p}<0.05$ of significance. The statistical analyses were performed using the program R (R Core Team 2016).

\section{RESULTS AND DISCUSSION}

The analysis of variance indicated that there was a significant triple interaction between sowing times $\times$ genotypes $\times$ densities for all evaluated variables (data not shown). Since the field experiments were carried out twice in the area, weather data can contribute to explain the obtained results. 
During the maize cycle under experimental conditions, the accumulated rainfall varied according to the harvest and sowing times (ST). In the first year, the rainfall accumulated reached 843, 780 and $1022 \mathrm{~mm}$, and in the second year, 1019, 903 and $755 \mathrm{~mm}$, in the sowing seasons ST1, ST2 and ST3, respectively (Figs. 1, 2). The rainfall values can be considered adequate for the maize crop, despite the irregular distribution, mainly in the third sowing time (ST3) of the 2016/2017 crop season.

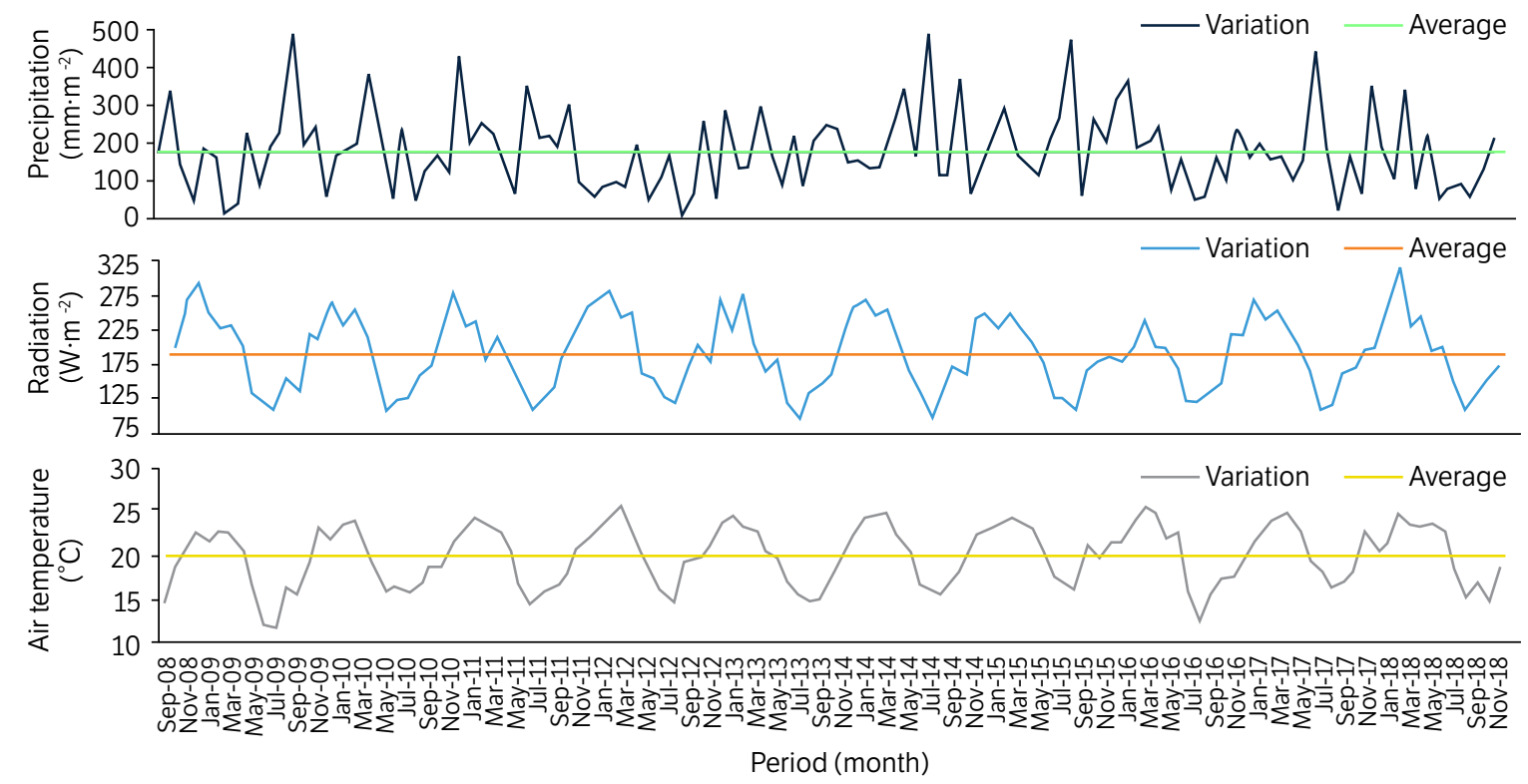

Figure 1. Historical weather data of the experimental unit.

Note. Monthly average of precipitation $\left(\mathrm{mm} \cdot \mathrm{m}^{-2}\right.$; up), radiation $\left(\mathrm{W} \cdot \mathrm{m}^{-2} ;\right.$ median) and average temperature $\left({ }^{\circ} \mathrm{C}\right.$; bottom) from 2008 from the automated weather station ( $27^{\circ} 05^{\prime} 24^{\prime \prime} \mathrm{S} ; 52^{\circ} 38^{\prime} 05^{\prime \prime} \mathrm{W}$ ), located at Chapecó, SC, Brazil, $5 \mathrm{~km}$ from the experimental unit.

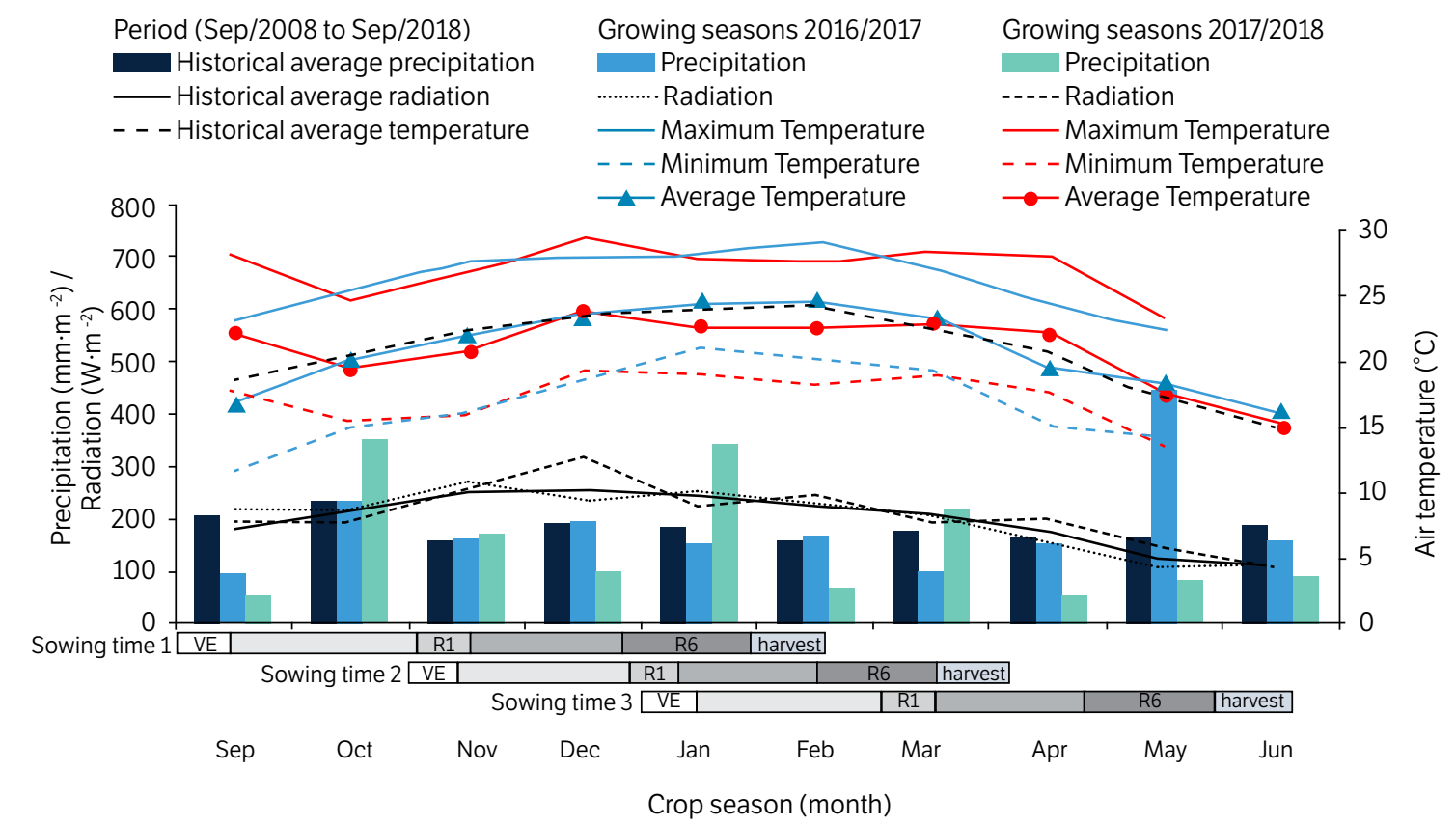

Figure 2. Weather conditions in the experimental unit.

Note. Monthly average of precipitation ( $\mathrm{mm} \cdot \mathrm{m}^{-2}$; columns), radiation $\left(\mathrm{W} \cdot \mathrm{m}^{-2}\right.$; black lines) and temperatures $\left({ }^{\circ} \mathrm{C}\right)$; blue, red and dashed black) from $2008 \mathrm{thru} 2018$, September 1, 2016 through June 30, 2017 and September 1, 2017 through May 31, 2018. The historical weather data were obtained from the Foz do Chapecó Energia S.A. and specifically the average minimum temperatures and average maximum temperatures from September 1, 2016 through May 31, 2018, were obtained from the automated weather station ( $27^{\circ} 05^{\prime} 24^{\prime \prime}$; $52^{\circ} 38^{\prime} 05^{\prime \prime}$ W), located at Empresa de Pesquisa Agropecuária e Extensão Rural de Santa Catarina, Chapecó, SC, Brazil (http://ciram.epagri.sc.gov.br/). Horizontal bars indicated the sowing times and the main maize phenological stages (Ransom and Endres 2020): $\mathrm{VE}=$ emergency, $\mathrm{R} 1$ = silks emerging and pollen shedding, and $\mathrm{R} 6=$ physiologic maturity. 
The evaluated sanitary attributes in the 2016/2017 growing season indicated that September and November are the sowing times with the lowest incidence of pathogens (Fig. 3a, c, e, g), regardless of genotype and sowing density. Similar results were found for the 2017/2018 growing season (Fig. 3b, d, f, h), for ST1, again with genotypes showing the lowest incidence of pathogens compared to ST2 and ST3. However, the incidence of pathogens on maize plants sown in November varied according to sowing density. The greater the sowing density, the higher the incidence of pathogens in the seeds. The highest incidence of pathogens was when seeds were sown in January, regardless of the crop and sowing density. The results indicate that late sowing favors the development of pathogens, which negatively affects the health quality of the seeds produced. Similar results were found for other maize genotypes, such as a super early hybrid in a monoculture, where a delay in sowing from the beginning to the end of spring increased, synergistically, the incidence of pathogens (Coelho et al. 2019).

Throughout the experiment of the first and second sowing times, the average temperatures were above $20^{\circ} \mathrm{C}$, which is above the minimum temperature necessary for good development of maize plants (Fig. 2). However, for the third sowing time, the average temperature fluctuated, with values below $20^{\circ} \mathrm{C}$ at the end of the crop cycle (April to June).

The combined effect of sowing season and genotype on incidence of pathogens on harvested seeds was also variable in the genotypes. When seeds were harvested from plants from the November sowing time of the 2017/2018 growing season, the incidences of pathogens at densities of 4.0 and 5.5 plants $\cdot \mathrm{m}^{-1}$ were 4.5 and $5.5 \%$, respectively, for Língua de Papagaio. This differed from the 15.0 and $12.5 \%$ averages for Taquara and 14.5 and $8.50 \%$ averages for SCS 155 Catarina, respectively at densities of 4.0 and 5.5 plants. $\mathrm{m}^{-1}$, the two genotypes with the highest seed incidence of pathogens for these sowing densities. The main pathogens associated with maize seeds responsible for physical damage (discoloration of the seeds, reduced carbohydrate content, proteins and total sugars) are Stenocarpela spp., Fusarium spp., Gibberella zeae, Penicillium spp., and Aspergillus spp. (Mendes et al. 2011; Siqueira et al. 2014).

Previously, in a study carried out with the same genotypes and environmental conditions as the present one, it was verified that the later the sowing is carried out, the greater the percentage of lodged and broken plants (Munarini and Nodari 2021). According to these authors, if both lodged and broken plants are taken together, the percentage of $4.6 \%$ in sowing carried out in September increased to $25.36 \%$ in sowing in November and to $36.52 \%$ in sowing in January. The lodged and broken plants are associated with the occurrence of rot that can be aggravated when the crop is sown late, due to the lower supply of radiation and better agroclimatic conditions for infection of the fungi that cause this problem (Sangoi et al. 2010)

Overall, for seed germination, higher germination percentages were observed for the September (91\%) and November (87\%) sowings, compared to sowing in January (79\%), for both analyzed growing seasons (Fig. 4). The smallest variation in germination percentages among genotypes was observed when sowing was carried out in September.

Specifically, the highest percentages of seed germination were observed in the sowing of September and November, compared to the sowing of January, in the two analyzed harvests; however, the genotypes showed different values for the germination percentage across densities and growing seasons (Fig. 4). The Branco Precoce is highlighted, because it showed statistically higher germination rate in September than in January in all evaluated treatment combinations except the sowing at density of 2.5 plants. $\mathrm{m}^{-1}$ of 2016/2017 (Fig. 4a). A similar result was exhibit by the SCS 155 Catarina genotype, which showed statistically superior germination rate in September compared to January in $75 \%$ of evaluated treatment combinations. For the genotypes Língua de Papagaio and Taquara, the superiority of the germination rate in seeding in September comparatively to January was proven in $50 \%$ of the treatment combinations. Overall, considering the minimum percentage of germination required for the commercialization of seeds in Brazil (85\%), 12\% of the combination of treatments sown in September, $28 \%$ in November and 59\% in January did not reach the minimum.

In the present study, a reduction in the percentage of seed germination was observed in seeds produced in second and third sowing times, regardless of the sowing density used. This result may be associated with a longer period of exposure to environmental factors until the seeds reach adequate humidity to harvest (20\%). Noal et al. (2014) studied the harvesting time of three maize landraces and found that the ideal harvest humidity for seeds of the genotypes varied from 20 to $30 \%$, since this humidity range had the highest percentages of germination and vigor. In the present study, when sowing was carried out in January, the incidence of diseases was higher compared to the other two sowing times, which reduced the percentage of seed germination. These results indicate that, for the studied genotypes, the ideal sowing time to obtain higher germination percentages is at the beginning of the period indicated for the climate zone for cultivating the species, which is September. In addition, sowing in January is not indicated to obtain seeds with the standard quality required by Brazilian law. 
(a)

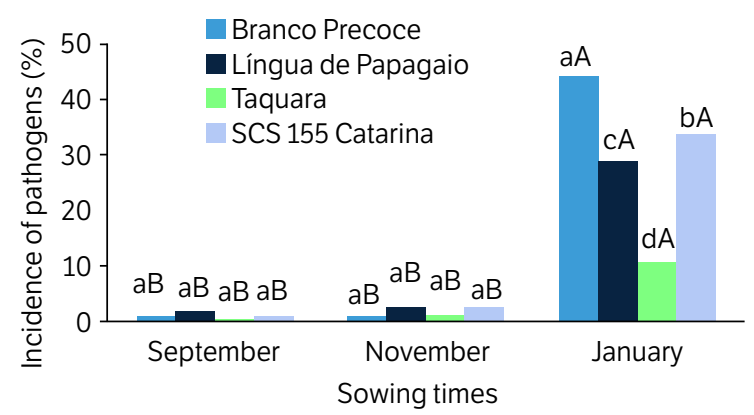

Density 2.5 plants. $\mathrm{m}^{-1}$ - harvest 2016/2017

(c)

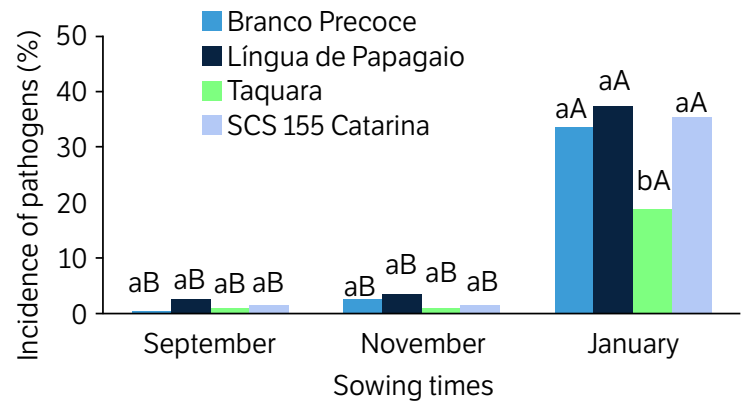

Density 4.0 plants. $\mathrm{m}^{-1}$ - harvest 2016/2017

(e)

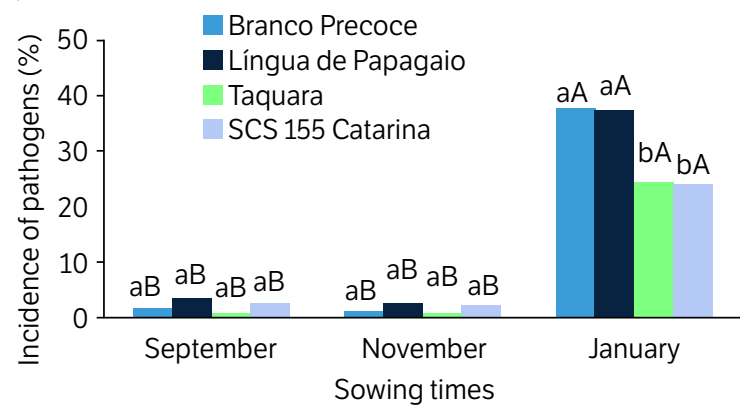

Density 5.5 plants. $\mathrm{m}^{-1}$ - harvest 2016/2017

(g)

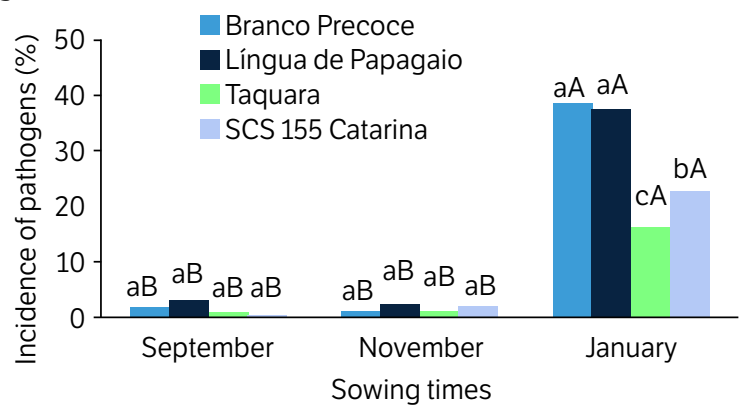

Density 7.0 plants. $\mathrm{m}^{-1}$ - harvest 2016/2017 (b)

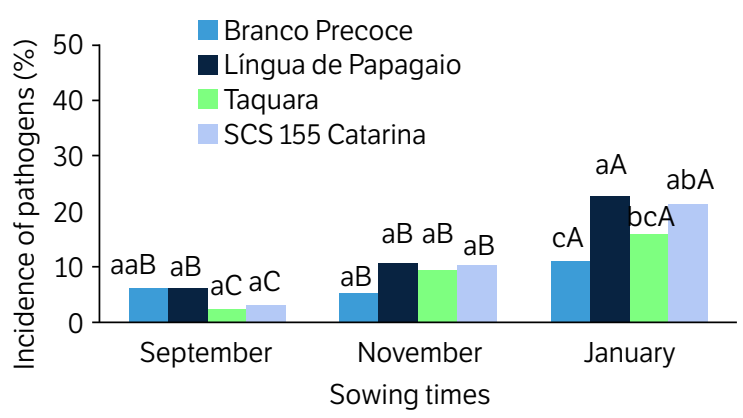

Density 2.5 plants $\cdot \mathrm{m}^{-1}$ - harvest 2017/2018

(d)

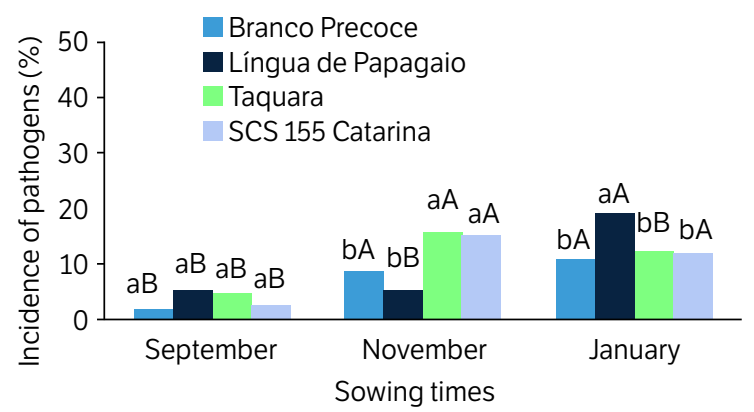

Density 4.0 plants $\cdot \mathrm{m}^{-1}$ - harvest 2017/2018

(f)

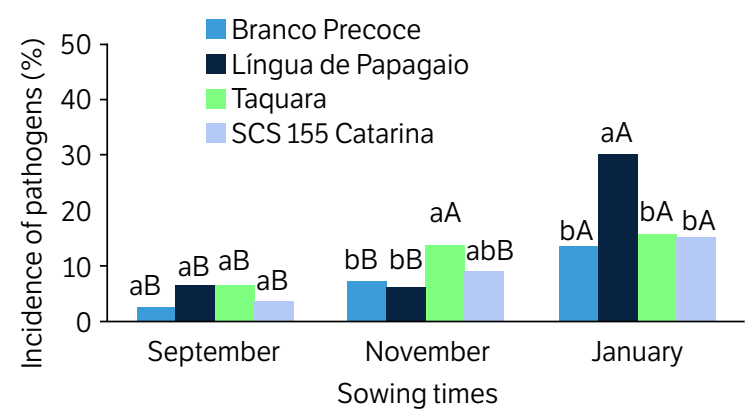

Density 5.5 plants $\cdot \mathrm{m}^{-1}$ - harvest 2017/2018

(h)

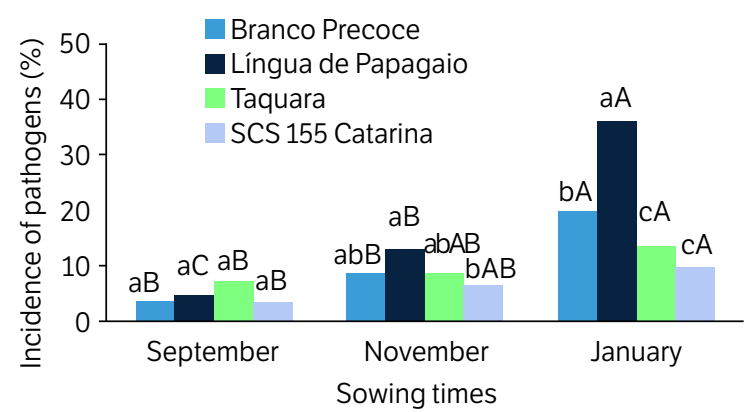

Density 7.0 plants. $\mathrm{m}^{-1}$ - harvest 2017/2018

Figure 3. Seed incidence of pathogens (\%) of maize genotypes in an agroecological system cultivated at three different sowing times (September, November and January) and four sowing densities of 2.5 plants $\cdot \mathrm{m}^{-1}(\mathrm{a}, \mathrm{b}), 4.0$ plants $\cdot \mathrm{m}^{-1}(\mathrm{c}, \mathrm{d}), 5.5 \mathrm{plants} \cdot \mathrm{m}^{-1}(\mathrm{e}, \mathrm{f})$ and $7.0 \mathrm{plants} \cdot \mathrm{m}^{-1}$ (g, h) in the 2016/2017 (a, c, e, g) and 2017/2018 (b, d, f, h) growing seasons, in Chapecó, Santa Catarina, Brazil.

Note. Means followed by the same lowercase letters, for each sowing time, and uppercase letters, for each genotype, do not differ by Tukey's test ( $<<0.05$ ). 


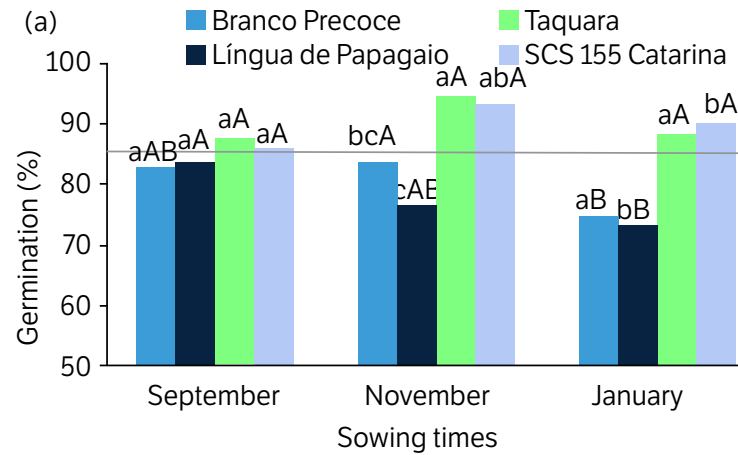

Density 2.5 plants $\cdot \mathrm{m}^{-1}$ - harvest 2016/2017
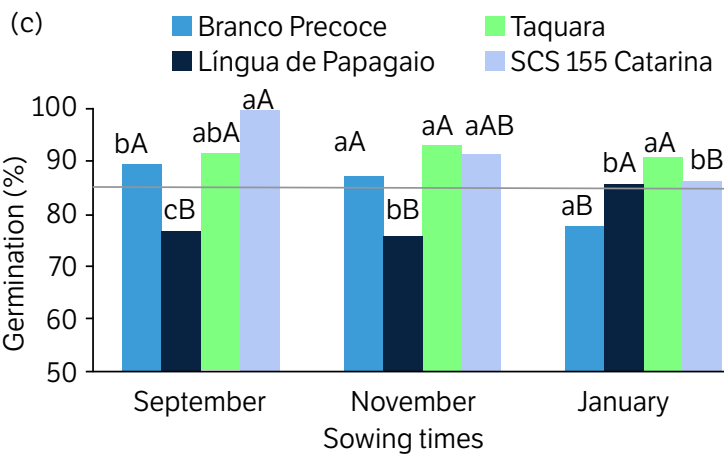

Density 4.0 plants $\cdot \mathrm{m}^{-1}$ - harvest $2016 / 2017$

(e)
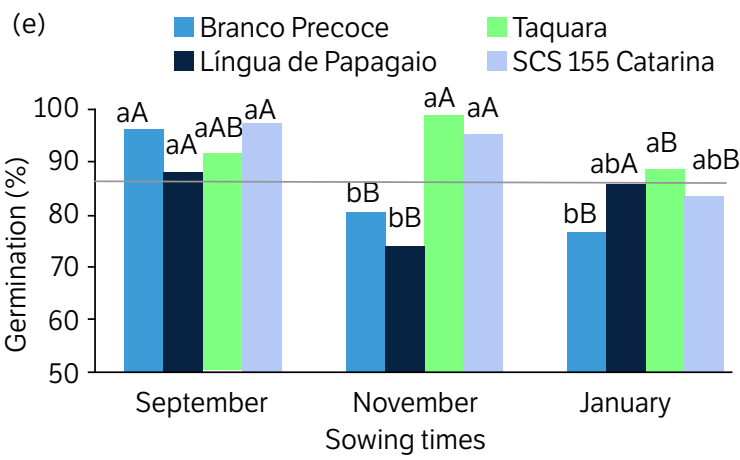

Density 5.5 plants $\cdot \mathrm{m}^{-1}$ - harvest 2016/2017

(g)

Branco Precoce Taquara

- Língua de Papagaio SCS 155 Catarina

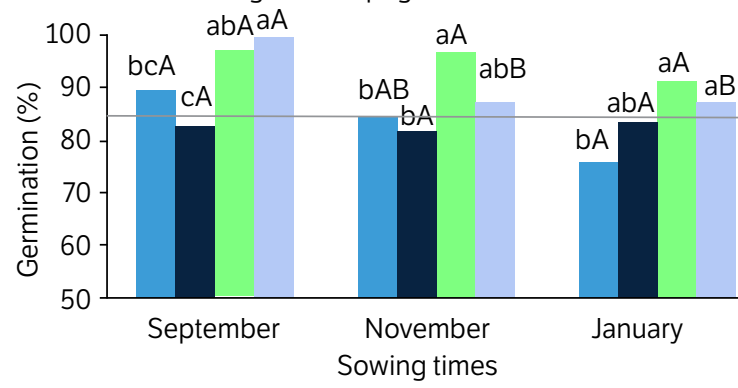

Density 7.0 plants. $\mathrm{m}^{-1}$ - harvest 2016/2017 (b)

Branco Precoce $\quad$ Taquara

- Língua de Papagaio SCS 155 Catarina

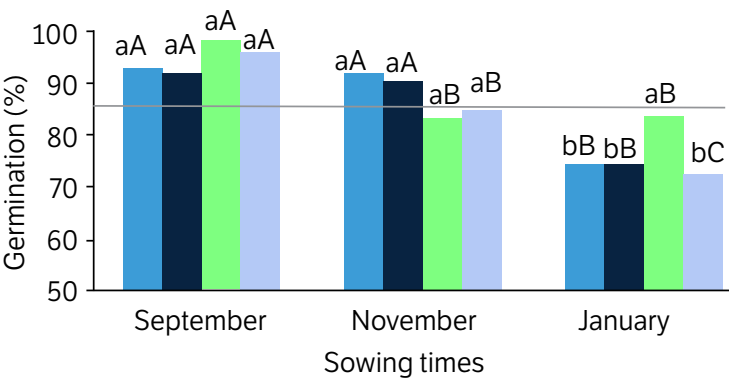

Density 2.5 plants $\cdot \mathrm{m}^{-1}$ - harvest $2017 / 2018$

(d)

Branco Precoce Taquara

- Língua de Papagaio SCS 155 Catarina

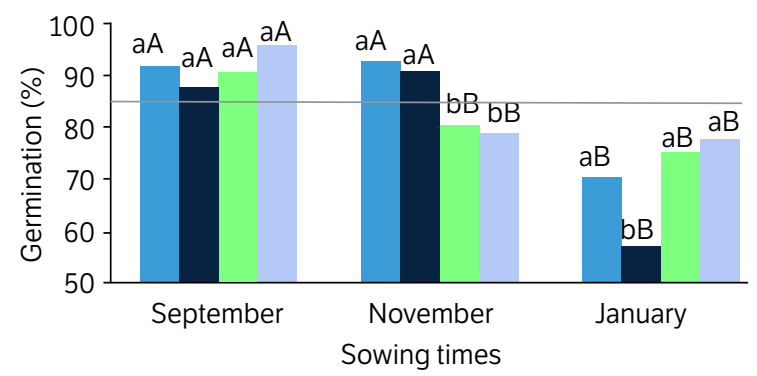

Density 4.0 plants $\cdot \mathrm{m}^{-1}$ - harvest 2017/2018

$\begin{array}{lll}\text { (f) } & \text { Branco Precoce } & \text { Taquara } \\ \text { Língua de Papagaio } & \text { SCS } 155 \text { Catarina }\end{array}$

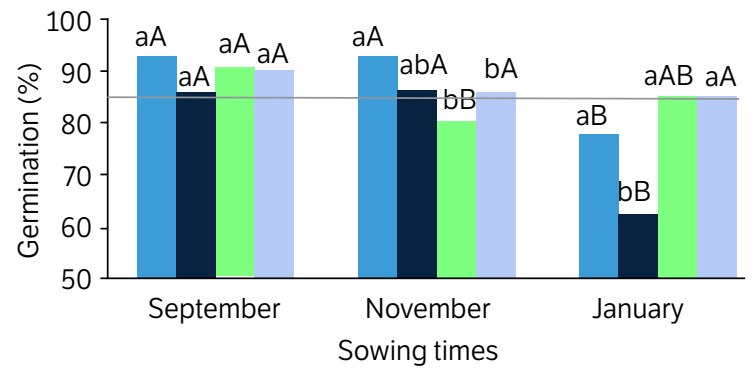

Density 5.5 plants $\cdot \mathrm{m}^{-1}$ - harvest 2017/2018

(h)

Branco Precoce Taquara

- Língua de Papagaio SCS155 Catarina

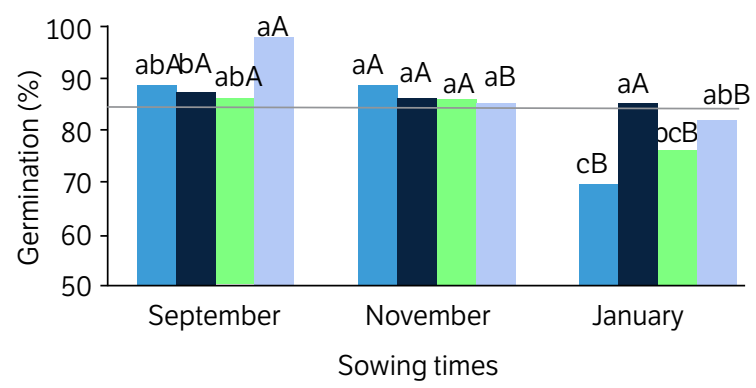

Density 7.0 plants $\mathrm{m}^{-1}$ - harvest 2017/2018

Figure 4. Percentage of germination of maize genotypes in an agroecological system cultivated at three different sowing times (September, November and January) and four sowing densities of 2.5 plants $\cdot \mathrm{m}^{-1}(\mathrm{a}, \mathrm{b}), 4.0$ plants $\cdot \mathrm{m}^{-1}(\mathrm{c}, \mathrm{d}), 5.5 \mathrm{plants} \cdot \mathrm{m}^{-1}(\mathrm{e}, \mathrm{f})$ and $7.0 \mathrm{pl} \cdot \mathrm{m}^{-1}(\mathrm{~g}, \mathrm{~h})$ in the 2016/2017 (a, c, e, g) and 2017/2018 (b, d, f, h) growing seasons, in Chapecó, Santa Catarina, Brazil.

Note. Means followed by the same lowercase letters, for each sowing time, and uppercase letters, for each genotype, do not differ by Tukey's test ( $p<0.05$ ). 
The genotypes tested in the present study differed for percentage of seed germination, demonstrating that there is variability among them (Fig. 4). The performance of the genotypes when sown in September was similar in both growing seasons. The cultivar SCS 155 Catarina exhibited an average germination of $95 \%$ in both growing seasons. For the same sowing time (ST1), seed germination was 92\% for the Taquara and 90\% for Branco Precoce genotypes in the two growing seasons. The Língua de Papagaio genotype had the lowest performance, with an average germination of $85 \%$ in both growing seasons. For the second sowing time (ST2), the germination percentages were different among the genotypes in the distinct growing seasons evaluated. While Língua de Papagaio still had the lowest performance in the first growing season, with an average seed germination of $77 \%$, in the second season (2017/2018) its performance was superior to Taquara and SCS 155 Catarina. Variations in genotype performance for each crop were also observed when seeds were sown in January (ST3), reaffirming the existence of diversity among genotypes that are exposed to different environmental factors.

Significant differences among maize landraces for percentage of germination were also verified by Queiroz et al. (2019) as one of the selection criteria in their breeding program. In addition, genetic diversity for physiological seed quality among genotypes was observed by Nerling et al. (2013) when analyzing intervarietal crosses of maize. On the contrary, Martin et al. (2018) evaluated maize seeds of open pollinated varieties and hybrids produced in organic systems and found no difference in germination percentages that were greater than $95 \%$.

In the present study, it was verified that the effect of sowing density varied according to the growing season. Considering the best sowing time (September), in the 2016/2017 growing season, Branco Precoce and Língua de Papagaio had the highest germination percentages at a density of 5.5 plants $\mathrm{m}^{-1}$. The genotypes Taquara and SCS 155 Catarina maintained the same germination percentage even at the density of 7 plants. $\mathrm{m}^{-1}$. In the 2017/2018 growing season, the genotypes Branco Precoce, Língua de Papagaio and Taquara exhibited a reduction in percentage of germination as the sowing seed density increased. However, the SCS 155 Catarina genotype was not affected by density, which is associated with the selection done during the cultivar development. Overall, the results suggest that the maize landraces do not tolerate dense cultivation (or intraspecific competition), especially when sown late in the season. Managing this feature relies on the practices of small farmers, where no high sowing density is used to produce grain, particularly in agroecological or organic polyculture systems.

In the evaluation of seed vigor (Fig. 5), the highest average vigor percentages were obtained from seeds sown in September and November, which were 80 and 68\%, respectively, for the 2016/2017 growing season and 74\% for both ST1 and ST2 in the following growing season. Sowing in January resulted in seeds with the lowest vigor performance, 66 and $56 \%$ in the two analyzed growing seasons, respectively. Percentages of vigor above $80 \%$ were verified only for sowing in September and November. Late sowing negatively affects the vigor of the seeds.

Among genotypes, the open pollinated cultivar SCS 155 Catarina and the Taquara landrace showed the highest percentage of seed vigor (87\%) when seeds were sown in September at a density of 2.5 plants $\mathrm{m}^{-1}$. On the other hand, for the Branco Precoce and Língua de Papagaio landraces, when sowing was carried out in November at densities of 4 and 5.5 plants. $\mathrm{m}^{-1}$ the seeds had a higher percentage of vigor ( 82 and $89 \%$, respectively). Língua de Papagaio was the most sensitive when sown in January, with an average vigor of $52 \%$.

The effect of sowing density on vigor varied according to the growing season and sowing time. Seed vigor percentage varied from $82 \%$ for the density 2.5 plants. $\mathrm{m}^{-1}$ to $70 \%$ for the density 7.0 plants $\cdot \mathrm{m}^{-1}$, when sowing was carried out in September in the 2017/2018 growing season. For the other two sowing times, the behavior in relation to density varied according to the genotype. In general, the higher the sowing density, the lower the seed vigor. The fact that density reduces the penetration of solar radiation into the canopy was noted by Sangoi and Silva (2016) to explain why high maize densities accelerate leaf senescence, reducing the duration of the grain filling period and promoting the production of light grains. In addition, an adverse effect of high sowing density seed production and physiological quality was verified in the present study.

As found in a study with other genotypes, the use of inadequate sowing densities and a delay in seed harvesting decrease the physiological quality of seeds and favor the attack of insects and microorganisms, accelerating the process of seed deterioration (Henning et al. 2011). In addition, sowing at the beginning of the recommended period for a crop in a certain region tends to benefit seed production with the required sanitary standards, due to the low pressure from pathogens (Martin et al. 2007). 


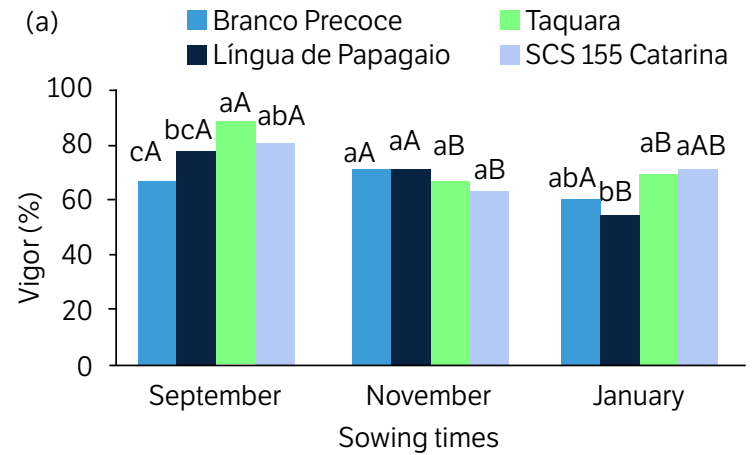

Density 2.5 plants. $\mathrm{m}^{-1}$ - harvest 2016/2017

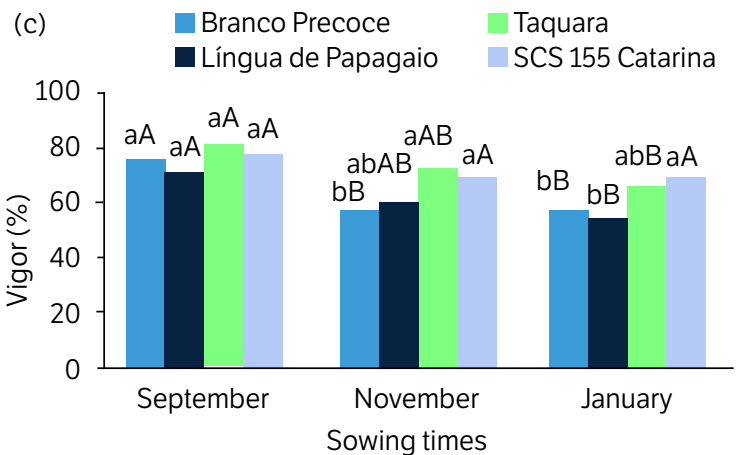

Density 4.0 plants $\cdot \mathrm{m}^{-1}$ - harvest $2016 / 2017$

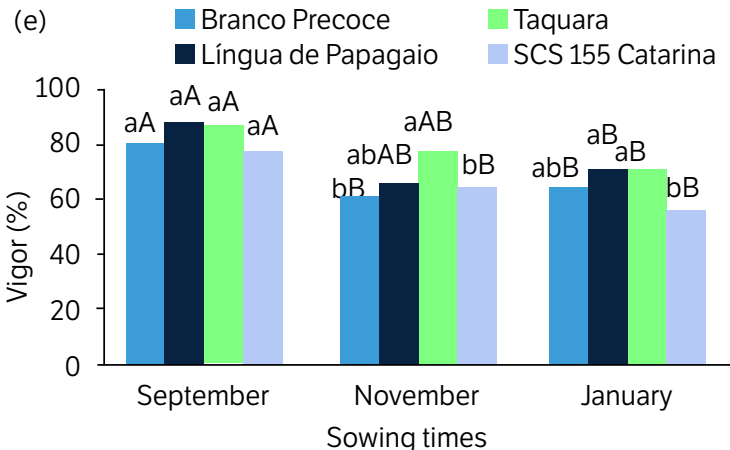

Density 5.5 plants $\cdot \mathrm{m}^{-1}$ - harvest $2016 / 2017$
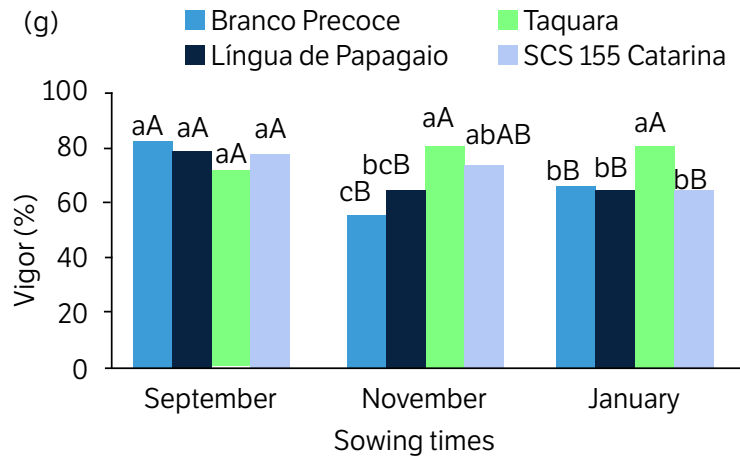

Density 7.0 plants. $\mathrm{m}^{-1}$ - harvest 2016/2017
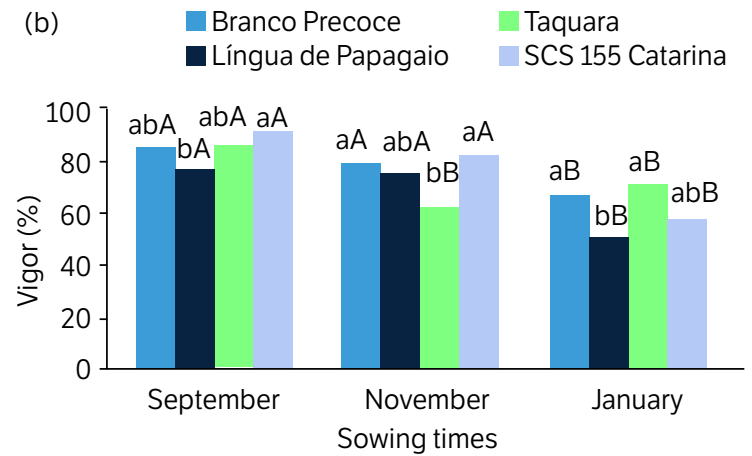

Density 2.5 plants $\cdot \mathrm{m}^{-1}$ - harvest $2017 / 2018$

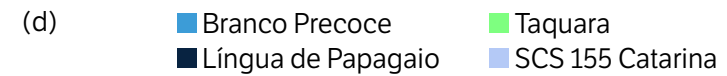

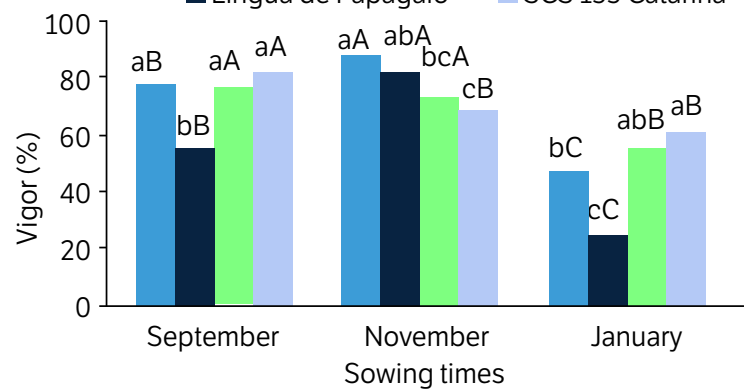

Density 4.0 plants $\cdot \mathrm{m}^{-1}$ - harvest 2017/2018
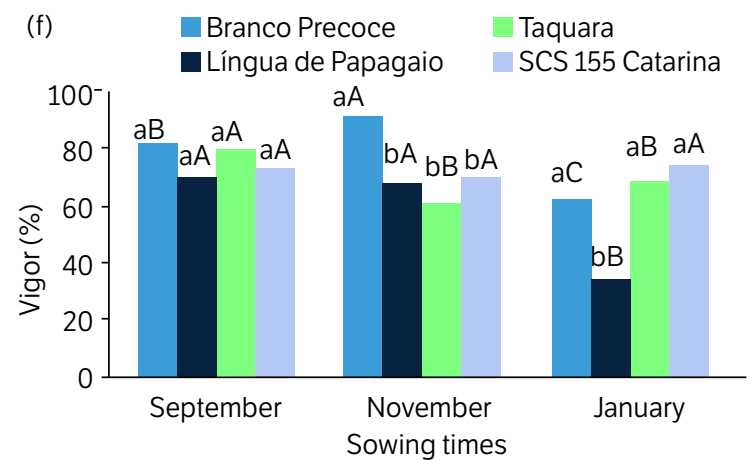

Density 5.5 plants $\mathrm{m}^{-1}$ - harvest 2017/2018

$\begin{array}{ll}\text { (h) } & \text { Branco Precoce } \\ \text { Língua de Papagaio } & \text { Taquara }\end{array}$

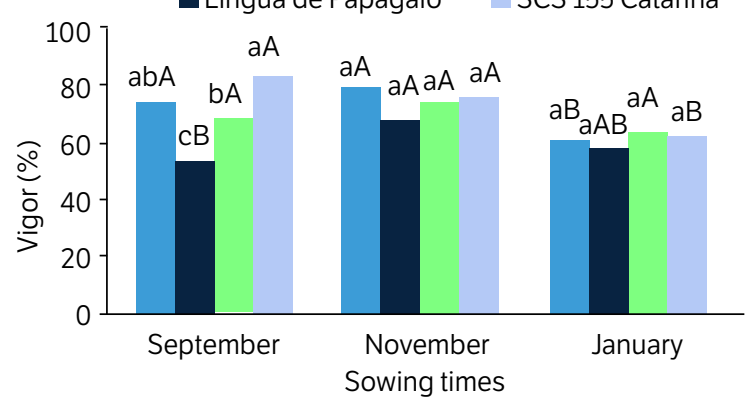

Density 7.0 plants. $\mathrm{m}^{-1}$ - harvest 2017/2018

Figure 5. Percentage of seed vigor of maize genotypes in an agroecological system cultivated at three different sowing times (September, November and January) and four sowing densities of 2.5 plants $\cdot \mathrm{m}^{-1}(\mathrm{a}, \mathrm{b}), 4.0$ plants $\cdot \mathrm{m}^{-1}(\mathrm{c}, \mathrm{d}), 5.5$ plants $\cdot \mathrm{m}^{-1}(\mathrm{e}, \mathrm{f})$ and $7.0 \mathrm{plants} \cdot \mathrm{m}^{-1}(\mathrm{~g}, \mathrm{~h})$ in the 2016/2017 (a, c, e, g) and 2017/2018 (b, d, f, h) growing seasons, in Chapecó, Santa Catarina, Brazil.

Note. Means followed by the same lowercase letters, for each sowing time, and uppercase letters, for each genotype, do not differ by Tukey's test ( $p<0.05$ ). 
The present study brings insight to two main issues. First, it supports the hypothesis that it is possible to produce organic or agroecological seeds that meet the legal requirements for commercial sowing. This result became relevant because high quality seeds from maize landraces can be produced and marketed. Consequently, the entire crop cycle for agroecological or organic systems (Brazil 2003) can be accomplished.

Second, the management practices tested, like sowing delay, do not allow farmers to avoid contamination of their landraces by transgenic hybrids without penalties, in terms of seed quality and quantity. In the region of the present study, which is currently recognized as a microcenter of maize diversity in western Santa Catarina, Brazil (Costa et al. 2017), the spatial isolation, to avoid transgenic contamination of landraces, also cannot be applied because of the proximity among farms, since $17,1 \%$ of them (<10 ha) produce maize landraces and the others nearby cultivate transgenic varieties (IBGE 2017).

Therefore, there is still no agronomic solution for small farmers that cultivate maize landraces in regions where transgenic hybrids are widespread without even minimal contamination. Earlier studies revealed the contamination of landraces after the legal release of transgenic varieties. Maize landraces from that maize diversity microcenter tested positive (19.1\% out of 157 samples) for the presence of transgenic proteins (Nerling et al. 2014), which was present in transgenic cultivated varieties in that region. In Spain, maize seed production in an organic area decreased by 75\% in Aragon between 2004 and 2007 and by 95\% in Catalonia from 2002 to 2008 because of the transgenic contamination (Binimelis et al. 2008).

Genetic contamination is the result of the gene flow that is accomplished by cross-pollination or seed mixture. In addition to commercial deficits, the flow of transgenes and their introgression into the valuable germplasm of important crop plants can cause unexpected consequences, disturb the genetic conservation, and affect public policies and crop management systems (Ellstrand 2003). The present article tested management practices of maize landraces in an agroecological system to avoid cross-pollination. The best one was the same sowing time as used for transgenic varieties. Spatial isolation also could avoid gene flow by cross-pollination, but not in the studied area due to proximity of farms (Costa et al. 2017). However, gene flow through seed mixtures was firstly demonstrated by Quist and Chapela (2001) in México. In that episode, transgenic seeds that contaminated Oaxaca maize landraces came from outside of the country. Fifteen years later, Oaxaca maize landraces continued with the transgenes (Agapito-Tenfen et al. 2017). Additionally, the authors claimed that transgenes extent and frequency depend on the societal characteristics and seed management systems of the local communities. Thus, even the farmers accept change the management practices, seed mixtures could also cause transgenic contamination of their landraces.

Thus, without options for temporal and spatial isolation without penalties, transgenic contamination of cultivating landraces in regions where transgenic varieties were released could happen at a large scale, which compromises the efforts of thousands of farmers that are conserving significant genetic diversity not yet represented in an ex situ germplasm bank.

Two subjects are of great importance for the sequence of studies on the use of landraces. The first refers to the need to test other landraces, because in this study we tested three out of hundreds of them with potential for use. If many tested landraces become available for cultivation, farmers could choose more than one to grow and thus have less risk of losses due to biotic and abiotic stresses. The second subject is related to climate change. Although landraces were tested during two growing cycles, their behavior may not be repeated in years with different climatic conditions from those that occurred during this study.

\section{CONCLUSION}

Seeds of maize landraces produced in agroecological systems with higher physiological quality and lower incidence of pathogens, standards required by Brazilian regulation, were obtained for the September (beginning of spring) sowing time at a density of 5.5 plants $\cdot \mathrm{m}^{-1}$.

When seed sowing is postponed to November (middle of spring), not all landraces or all sowing densities tested provide seeds of high quality and with the required standard due to the adverse effects of the interaction of genotypes $\times$ densities $\times$ sowing times.

For the first time, evidence was found that postponing planting even further by sowing seeds in January to avoid contamination by maize transgenic hybrids not only the harvested seed acquire the legal standard and the desired quality to be sown next season, but also provoked lesser yield. 
Overall, temporal isolation of landraces cultivated in agroecological or organic systems for seed production is not a solution for small farmers to avoid transgenic contamination of maize landrace because of loss of yield and seed quality.

Considering that there were differences between landraces in terms of vigor and seed germination rate in late plantings, it is recommended that farmers test several landraces adapted to their region on a small scale before commercial planting.

\section{AUTHORS' CONTRIBUTION}

Conceptualization: Munarini, A. and Nodari, R. O.; Methodology: Munarini, A., Nodari, R. O., Nerling, D. and Coelho, C. M. M.; Investigation: Munarini, A.; Writing - Original Draft: Munarini, A., Nodari, R. O., Nerling, D. and Coelho, C. M. M.; Writing -Review \& Editing: Munarini, A., Nodari, R. O., Nerling, D. and Coelho, C. M. M.; Funding Acquisition: Munarini, A., Nodari, R. O. and Nerling, D.; Resources: Nodari, R. O. and Coelho, C. M. M.; Supervision: Nodari, R. O.

\section{DATA AVAILABILITY STATEMENT}

Data are available under request.

\section{FUNDING}

Conselho Nacional de Desenvolvimento Científico e Tecnológico

[https://doi.org/10.13039/501100003593]

Grant No. 403720/2013-3 and 303902/2017-5

Coordenação de Aperfeiçoamento de Pessoal de Nível Superior

[https://doi.org/10.13039/501100002322]

Finance Code 001

\section{ACKNOWLEDGMENTS}

The authors would like to thank the Oestebio Cooperative and the Movimento dos Pequenos Agricultores (MPA) for their partnership in the field experiments.

\section{REFERENCES}

[IBGE] Instituto Brasileiro de Geografia e Estatística. (2017). Censo agropecuário. Tabela 6958 - Produção, Valor da produção, Venda, Valor da venda e Área colhida da lavoura temporária nos estabelecimentos agropecuários, por tipologia, produtos da lavoura temporária, tipo de semente e grupos de área colhida. Sistema IBGE de Recuperação Automática - SIDRA. [Accessed Aug. 19, 2019]. Available at: https://sidra.ibge.gov.br/tabela/6958

Agapito-Tenfen, S., Lopez, F. R., Mallah, N., Abou-Slemayne, G., Trtikova, M., Nodari, R. O. and Wickson, F. (2017). Transgene flow in Mexican maize revisited: Socio biological analysis across two contrasting farmer communities and seed management systems. Ecology and Evolution, 7, 9461-9472. https://doi.org/10.1002/ece3.3415 
Altieri, M. A., Nicholls, C. I., Henao, A. and Lana, M. A. (2015). Agroecology and the design of climate change-resilient farming systems. Agronomy for Sustainable Development, 35, 869-890. https://doi.org/10.1007/s13593-015-0285-2

Amorim, F. A., Hamawaki, O. T., Sousa, L. B., Lana, R. M. Q. and Hamawaki, C. D. L. (2011). Época de semeadura no potencial produtivo de soja em Uberlândia - MG. Semina: Ciências Agrárias, 32, 1793-1802. https://doi.org/10.5433/1679-0359.2011v32n4Sup1p1793

Araujo, A. V., Brandão Junior, D. S., Ferreira, I. C. P. V., Costa, C. A. and Porto, B. B. A. (2013). Desempenho agronômico de variedades crioulas e híbridos de milho cultivados em diferentes sistemas de manejo. Revista Ciência Agronômica, 44, 885-892. https://doi. org/10.1590/S1806-66902013000400027

Balbinot Junior, A. A., Backes, R. L., Alves, A. C., Ogliari J. B. and Fonseca, J. A. (2005). Contribuição de componentes de rendimento na produtividade de grãos em variedades de polinização aberta de milho. Revista Brasileira de Agrociência, 11, 161-166.

Binimelis, R. (2008). Coexistence of Plants and Coexistence of Farmers: Is an Individual Choice Possible? Journal of Agricultural and Environmental Ethics, 21, 437-457. https://doi.org/10.1007/s10806-008-9099-4

Brazil. Ministério da Agricultura, Pecuária e Abastecimento. (2003). Lei no 10.831, de 23 de dezembro de 2003. Dispõe sobre a agricultura orgânica e dá outras providências. Diário Oficial da União: Brasília. [Accessed Aug. 19, 2019]. Available at: http://www.planalto.gov.br/ ccivil_03/leis/2003/l10.831.htm\#

Brazil. Ministério da Agricultura e reforma Agrária. (2009). Regras para análises de sementes. Brasília: Mapa/ACS.

Brazil. Ministério da Agricultura, Pecuária e Abastecimento. (2013). Instrução Normativa n 45, de 17 de setembro de 2013 . Padrões de identidade e qualidade para produção e comercialização de sementes. Diário Oficial da União: Brasília.

Bornhofen, E., Benin, G., Galvan, D. and Flores, M. F. (2015). Épocas de semeadura e desempenho qualitativo de sementes de soja. Pesquisa Agropecuária Tropical, 45, 46-55. https://doi.org/10.1590/1983-40632015v4529143

Coelho, C. M. M., Mota M. R., Souza C. A. and Miquelluti D. J. (2010). Potencial Fisiológico em Sementes de Cultivares de Feijão Crioulo (Phaseolus vulgaris L.). Revista Brasileira de Sementes, 32, 97-105. https://doi.org/10.1590/S0101-31222010000300011

Coelho, A. E., Sangoi, L., Casa, R. T., Kuneski, H. F., Panison, F., Leolato, L. S., Durli, M. M. and Berghetti, J. (2019). Sanidade de híbridos de milho em função da época de semeadura, doses de $\mathrm{N}$ em áreas com e sem rotação de culturas. Colloquium Agrariae, $15,101-113$. https://doi.org/10.5747/ca.2019.v15.n2.a289

Costa, F. M., Silva, N. C. A. and Ogliari, J. B. (2017). Maize diversity in southern Brazil: indication of a microcenter of Zea mays L. Genetic Resources and Crop Evolution, 64, 681-700. https://doi.org/10.1007/s10722-016-0391-2

Ellstrand, N. C. (2003). Current knowledge of gene flow in plants: implications for transgene flow. Philosophical Transactions of the Royal Society of London B, Biological Sciences, 358, 1163-1170. https://doi.org/10.1098/rstb.2003.1299

Harlan J. R. (1951). Anatomy of Gene Centers. The American Naturalist, 85, 97-103. https://doi.org/10.1086/281657

Henning, F. A., Jacob Junior, E. A., Mertz, L. M. and Peske, S. T. (2011). Qualidade sanitária de sementes de milho em diferentes estádios de maturação. Revista Brasileira de Sementes, 33, 316-321. https://doi.org/10.1590/S0101-31222011000200014

Jaureguy, L. M., Rodriguez, F. L., Zhang, L., Chen P., Brye K., Oosterhuis, D., Mauromoustakos, A. and Clark, J. R. (2013). Planting Date and Delayed Harvest Effects on Soybean Seed Composition. Crop Science, 53, 2162-2175. https://doi.org/10.2135/cropsci2012.12.0683

Machado, A. T., Machado, C. T. T., Nass, L. L. (2011). Manejo da diversidade genética e melhoramento participativo de milho em sistemas agroecológicos. Revista Brasileira de Agroecologia. 6, 127-136.

Marcos-Filho, J. (2005). Fisiologia de sementes de plantas cultivadas. Piracicaba: FEALQ.

Martin, B. C., Fontanetti, A., Conceição, P. M., Lourenço, O. and Silva Neto, F. J. (2018). Potencial fisiológico das sementes de genótipos de milho produzidas em sistema orgânico. Revista Ciência, Tecnologia e Meio Ambiente, 7, 62-68. https://doi.org/10.4322/2359-6643.07108 
Martin, T. N., Tomazella, A. L., Cícero, S. M., Dourado Neto, D. D, Favarin, J. L. and Vieira Júnior, P. A. (2007). Questões relevantes na produção de sementes de milho - primeira parte. Revista da Faculdade de Zootecnia, Veterinária e Agronomia. 14, 119-138.

Mazvimbakupa, F., Modi, A. T. and Mabhaudhi, T. (2015). Seed quality and water use characteristics of maize landraces compared with selected commercial hybrids. Chilean Journal of Agricultural Research 75, 13-20. https://doi.org/10.4067/S0718-58392015000100002

Mendes, M. C., Von Pinho, R. G., Machado, J. C., Albuquerque, C. J. B. and Falquete, J. C. F. (2011). Qualidade sanitária de grãos de milho com e sem inoculação a campo dos fungos causadores de podridões de espigaspiga. Ciência e Agrotecnologia, 35, 931-939. https:// doi.org/10.1590/S1413-70542011000500010

Meotti, G. V., Benin, G., Silva, R. R., Beche, E. and Munaro, L. B. (2012). Épocas de semeadura e desempenho agronômico de cultivares de soja. Pesquisa Agropecuária Brasileira, 47,14-21. https://doi.org/10.1590/S0100-204X2012000100003

Munarini, A. and Nodari, R. O. (2021). Effect of sowing time and density for vegetative and reproductive traits of genotypes of maize landrace in an agroecological system. Ciência Rural, 51, e20200145. https://doi.org/10.1590/0103-8478cr20200145

Nerling, D, Coelho, C. M. M. and Nodari, R. O. (2013). Genetic diversity for physiological quality of seeds from corn (Zea mays L.) intervarietal crossbreeds. Journal of Seed Science. 35, 449-456. https://doi.org/10.1590/S2317-15372013000400006

Nerling, D., Munarini, A., Carboni, D., Silva, M. T. and Kittel, L. (2014) Contaminação genética de campos de produção de sementes de milho por transgênicos. Cadernos de Agroecologia, 9.

Noal, G., Muniz, M. F. B., Henning, L. M. M. and Barbieri, M. (2014). Ponto de colheita de sementes de cultivares crioulas de milho no Rio Grande do Sul. Pesquisa Agropecuária Pernambucana. 19, 79-84. https://doi.org/10.12661/pap.2014.012

Queiroz, T. N., Valiguzski, A. L., Braga, C. S., Souza, S. A. M. and Rocha A. M. (2019). Avaliação da Qualidade Fisiológica de Sementes de Variedades Tradicionais de Milho. Revista da Universidade Vale do Rio Verde, 17, 1-9. https://doi.org/10.5892/ruvrd.v17i1.5130

Quist, D. and Chapela, I. H. (2001). Transgenic DNA introgressed into traditional maize landraces in Oaxaca, Mexico. Nature 414, 541543. https://doi.org/10.1038/35107068

R Core Team (2016). A language and environment for statistical computing. R Foundation for Statistical Computing. Vienna: Austria. [Accessed May 11, 2021]. Available at: https://www.R-project.org/

Rahman, M. M., Rahman, M. M. and Hossain, M. M. (2013). Effect of Sowing Date on Germination and Vigour of Soybean (Glycine max (L.) Merr) Seeds. The Agriculturists, 11, 67-75. https://doi.org/10.3329/agric.v11i1.15245

Ransom, J. and Endres G. (2020). Corn Growth and Management Quick Guide [A1173]. Fargo: North Dakota State University. [Accessed Jan. 24, 2021]. Available at: https://www.ag.ndsu.edu/publications/crops/corn-growth-and-management-quick-guide

Sangoi, L., Silva, P. R. F., Argenta, G. and Rambo, L. (2010). Ecofisiologia da cultura do Milho para altos rendimentos. Lages: Graphel.

Sangoi, L. and Silva, P. R. F. (2016). Estratégias de manipulação do arranjo de plantas e desempenho agronômico do milho. In J. A. W. Filho, and L. A. Chiaradia (Eds.), A cultura do milho em Santa Catarina. (p. 85-121). Florianópolis: Epagri.

Siqueira, C. S, Machado, J. C., Corrêa, C. L. and Barrocas, E. N. (2014). Colonization of maize seeds by two species of Stenocarpella transformed with fluorescent proteins and assessed through scanning electron microscopy. Journal of Seed Science, 36, 168-177. https:// doi.org/10.1590/2317-1545v32n2918

Zeven, A. C. (1998). Landraces: A review of definitions and classifications. Euphytica, 104, 127-139. https://doi.org/10.1023/A:1018683119237 